OPEN ACCESS

Approved by:

Frontiers Editorial Office,

Frontiers Media SA, Switzerland

${ }^{*}$ Correspondence:

Huan Huang

dochappy@126.com

Lei Yin

pumayl@163.com

tThese authors have contributed equally to this work

Specialty section:

This article was submitted to

Cancer Genetics,

a section of the journal

Frontiers in Oncology

Received: 29 July 2020

Accepted: 30 July 2020

Published: 18 September 2020

Citation:

Han L, Zhang X, Wang A, Ji Y, Cao X Qin Q, Yu T, Huang H and Yin L (2020)

Corrigendum: A Dual-Circular RNA

Signature as a Non-invasive Diagnostic Biomarker for Gastric Cancer. Front. Oncol. 10:1704. doi: 10.3389/fonc.2020.01704

\section{Corrigendum: A Dual-Circular RNA Signature as a Non-invasive Diagnostic Biomarker for Gastric Cancer}

\author{
Li Han ${ }^{1,2 \dagger}$, Xiaoying Zhang ${ }^{3 \dagger}$, Aimin Wang ${ }^{1 \dagger}$, Yang $\mathrm{Ji}^{2}$, Xuelei Cao ${ }^{3}$, Qiaoji Qin ${ }^{3}$, Tao Yu ${ }^{3}$ \\ Huan Huang ${ }^{3 *}$ and Lei Yin ${ }^{3 *}$ \\ ${ }^{1}$ School of Nursing, Qingdao University, Qingdao, China, ${ }^{2}$ Department of Cardiology, The Affiliated Hospital of Qingdao \\ University, Qingdao, China, ${ }^{3}$ Department of Emergency Internal Medicine, The Affiliated Hospital of Qingdao University, \\ Qingdao, China
}

Keywords: gastric cancer, circRNAs, plasma, diagnosis, signature, Hsa_circ_0020187, Hsa_circ_0005051

\section{A Corrigendum on}

A Dual-Circular RNA Signature as a Non-invasive Diagnostic Biomarker for Gastric Cancer by Han, L., Zhang, X., Wang, A., Ji, Y., Cao, X., Qin, Q, et al. (2020). Front. Oncol. 10:184. doi: $10.3389 /$ fonc.2020.00184

In the original article the author order was incorrectly given as Lei Yin and Huan Huang. The correct order is Huan Huang and Lei Yin.

The authors apologize for this error and state that this does not change the scientific conclusions of the article in any way. The original article has been updated.

Copyright $\odot 2020$ Han, Zhang, Wang, Ji, Cao, Qin, Yu, Huang and Yin. This is an open-access article distributed under the terms of the Creative Commons Attribution License (CC BY). The use, distribution or reproduction in other forums is permitted, provided the original author(s) and the copyright owner(s) are credited and that the original publication in this journal is cited, in accordance with accepted academic practice. No use, distribution or reproduction is permitted which does not comply with these terms. 